DOI: https://doi.org/10.32839/2304-5809/2021-4-92-61

уДК 341.174

Тимчишин Т.М., Лозинський Ю.P. Львівський державний університет внутрішніх справ

\title{
СУД ЄВРОПЕЙСЬКОГО СОЮЗУ: ПОРЯДОК ФОРМУВАННЯ І ПОВНОВАЖЕННЯ
}

Анотація. У вітчизняній науці активно вивчається система інституцій Свропейського Союзу (далі - СС). Особливо актуальним це стало з підписанням «Угоди про асоціацію» між Україною та ЄС. Сьогодні $€$ значна кількість наукових праць, що присвячені вивченню фрунціонування та розвитку інституційних органів ЄС. Серед інституційних органів визначальну роль у процесі тлумачення норм права та забезпечення розвитку правової системи ЄС належить Суду Свропейського Союзу. Разом з тим не достатньо уваги науковців присвячено, системному вивченню правової природи судової системи ЄС, ії становленню та повноваженням. Вивчення розвитку правової системи ЄС, а особливо судової системи ЄС, дає можливість проникнути в суть правотворчих процесів, які сприяли розвитку судової системи ЄС.

ключові слова: Судова система ЄС, Суд ЄС, Загальний Суд, держава-член ЄС, Лісабонська угода.

Tymchyshyn Taras, Lozynsky Yuri Lviv State University of Internal Affairs

\section{COURT OF JUSTICE OF THE EUROPEAN UNION: PROCEDURE FOR FORMATION AND POWERS}

Summary. The system of institutions of the European Union is actively studied in domestic science. This became especially relevant with the signing of the "Association Agreement" between Ukraine and the EU. Today, there are many scientific papers devoted to the study of the functioning and development of EU institutional bodies. Among the institutional bodies, the Court of Justice of the European Union plays a key role in the process of interpreting EU law and ensuring the development of the EU legal system. At the same time, not enough attention is paid to the systematic study of the legal nature of the EU judicial system, its formation and powers. Studying the development of the EU legal system, and especially the EU judicial system, will give us the opportunity to get to the heart of the law-making processes that have contributed to the development of the EU judicial system. From the very first years of its existence, the European Union has had an independent and authoritative branch of government - the judiciary. At the top of which is the Court of Justice of the European Communities, established in 1952. Being not only law enforcement but also an interpretive institution, the Court of Justice of the European Union has played a significant role in affirming the fundamental foundations of Community and Union law. The Court of Justice of the European Union is a key element of the EU's institutional system in the functioning of the EU's institutional bodies. The study of the development of the Court of Justice in the institutional EU provides an opportunity to clarify not only the nature of the intergovernmental association, but also the structure and functional role of the Court of Justice in the development of integration processes. European law is one of the most important instruments of European integration. Among the many factors that contribute to integration processes, law plays an important role. It is thanks to the development of European law that not only a single legal space is formed, but also the necessary conditions and preconditions for a single economic space, a single cultural space are created, and everything necessary to ensure unity is created. It is through legal means that it is possible to overcome the difficulties and difficulties that are inevitable in creating a new public legal integration entity in terms of its qualitative parameters, which is the European Union.

Keywords: EU judicial system, Court of Justice, General Court, EU Member State, Lisbon Treaty.

$\Pi$ остановка проблеми. Створення та розбудова Європейських співтовариств, а згодом Свропейського Союзу здійснювались на певній юридичній основі. Відповідно, оформлення та правова база Євросоюзу, його структура, цілі, завдання, умови та порядок діяльності - все це повинно було знайти своє відображення та закріплення в нормах европейського права. В свою чергу, створення единої системи европейського права неможливе без існування судових органів.

Судова система СС була створена з метою вирішення суперечок між державами-членами співтовариств, шляхом тлумачення його норм та імплементації норм права СС у внутрішне законодавство держав-членів як передумова для нормального функціонування організаційно правового механізму европейської інтеграції.

Аналіз останніх досліджень і публікацій. Стан теорії юрисдикції Суду ЄС були предметом спеціальних наукових досліджень таких науков- ців: Т. М. Анікіної, О. Андрійчука, М. В. Буроменського, Т. В. Комарової, М. М. Микієвича, О. М. Москаленка, В. І. Муравйова, Р. Петрова, О. Я. Трагнюка, О. М. Яковлюка та ін.

Виділення не вирішених раніше частин загальної проблеми. Пропонуеться історикоправовий аналіз становлення судової системи ЄC, через синтез судовими органами повноважень захисту правової природи ЄС.

Мета статті. Головною метою цієї роботи є гносеологічний аналіз становлення Суду Європейського Союзу та аналіз його повноважень.

Виклад основного матеріалу. 3 моменту створення Суду Європейського Союзу в 1952 році в м. Люксембург, його місія полягала в забезпеченні дотримання співтовариствами Установчих договорів під час їх тлумачення та застосування. Як зазначає К. Ю. Голуб, Суд ЄС завоював незаперечний авторитет гаранта європейського права. Залишаючись осторонь численних політичних 
суперечок (Суд СС є чисто фрункціональним спеціалізованим інститутом неполітичного характеру), що властиві європейському об'єднавчому процесу, Суд СС намагався неухильно виконувати свою юридичну функцію, набуваючи характеру рушійної сили європейської інтеграції [1].

Судова практика, створена Судом, - одна з найважливіших передумов створення та розвитку якісних джерел права Свропейського Союзу, яка поширює дію на всі держави-члени і їх органи.

За допомогою своїх нормативних рішень Суд ЄC послідовно окреслює Федеративні риси ЄС, що відобразилися у формуванні його суті Договором про Функціонування ЄС 1957 р.

Заснування Свроатому і Свропейського економічного співтовариства передбачало формування самостійної інституційної системи для кожного 3 них, однак як і у випадку з Асамблеєю, було вирішено створити не три самостійні Суди, а спільний для трьох Співтовариств Суд, який після набуття чинності в 1967 р. Договору про злиття став іменуватися Судом Свропейських співтовариств.

Якщо на момент створення на Суд покладався обов'язок вирішувати спори між державами - членами ССВС і слідкувати за дотриманням ними норм установчого договору, то після підписання Римських договорів він отримав право здійснення судового контролю, що дозволило розглядати справи стосовно законності правових актів Свропейських співтовариств. У подальшому на Суд ЄС було покладено завдання стосовно забезпечення однакового тлумачення й застосування права ЄC на території всіх держав - членів об'єднання [2].

Протягом довгого часу Суд СС був единим судовим інституційним органом співтовариств. Кількість справ, що були у його провадженні було невеликим, i він швидко справлявся 3 їх розглядом. Проте поступово ситуація змінилася. Так, якщо за весь 1957 року Суд СС виніс чотири рішення, то у 1967 р. - двадцять чотири, то в 1977 р. число винесених рішень досягло ста, а в 1987 р. - кількість рішень ще подвоїлась.

Постійне зростання навантаження на єдиний судовий інститут сприяло відповідним реформам: на підставі поправок, внесених до установчих договорів в 1986 р., був створений другий утворений орган Співтовариств - Трибунал першої інстанції. До юрисдикції Трибуналу перейшли справи за скаргами фізичних та юридичних осіб на дії (бездіяльність) інститутів і органів СС, а також службові суперечки (спори, що виникають у зв'язку 3 проходженням цивільної служби Свропейських спільнот).

Таким чином, Суд СС отримав можливість зосередитися на вирішенні справ «конституційного» характеру. Трибунал першої інстанції виступає переважно в ролі органу адміністративної юстиції.

При цьому, на відміну від Суд СС, Трибунал не був окремим інститутом Свропейського Союзу. Це орган, що працював у складі суду СС, що має 3 ним одне місцезнаходження (Люксембург) і загальним оглядом апарат.

Створення Міжнародного Трибуналу, в подальшому, не дало змоги вирішити проблему перевантаженості справами судової системи СС, яка поступово лише погіршилася у зв'язку зі вступом до $Є$ С десятки нових держав-членів. Так, в 2002 р. Суд виніс 269 рішень (в тому ж році йому у провадження надійшло 470 нових справ). Трибунал в зазначений період завершив розгляд - 331 справи (надійшло - 411). Середня тривалість розгляду справ зросла до двох років.

3 урахуванням ціеї ситуації пов'язаної з Ніццьким договором 2001 року Рада ЄС отримала право засновувати нові судові органи спеціальної юрисдикції в якості третьої (нижнього) ланки судової системи СС. Ця ланка отримала узагальнене найменування «судові палати», або «спеціалізовані трибунали» (останній термін $\epsilon$ більш коректним; саме він використаний в Лісабонському договорі 2007 р.) До компетенції судових палат (спеціалізованих трибуналів) могли передаватися строго певні категорії справ позовного провадження, нині розглядаються Судом або Трибуналом (тут і далі під Трибуналом маеться на увазі Трибунал першої інстанції).

У 2004 рощі був створений перший спеціалізований суд Свропейського Союзу - Трибунал у справах публічної служби. У його юрисдикщію передані суперечки між Свропейським Союзом, 3 одного боку, і особами, які перебувають на його «европейської публічній службі» (аналог державної служби), а також іншими співробітниками апарату ЄC, з іншого боку. На відміну від Суду ЄC кількісний склад Трибуналу чітко не визначено - відповідно до ст. 254 ДФСС чисельність суддів Трибуналу визначається Статутом Суду ЄС.

Держави-члени СС на посаду суддів призначають в основному колишніх суддів держав-членів ЄC, практикуючих юристів або науковців. Судді і генеральні адвокати, призначаються посаду строком на шість років за загальною згодою урядів держав-членів ЄС. Кожні три роки відбувається часткова заміна суддівського складу. Судді мають обирати Голову Суду строком на три роки. Суд ЄС засідає в палатах по три судді чи по п'ять суддів, у Великій палаті з 13 суддів за вимогою інституту чи держави-члена, які $є$ стороною по справі, або в повному складі (пленум) у виняткових випадках, передбачених пп. 4, 5 ст. 16 Статуту Суду [4].

Суд ЄС складається 3 одного судді від кожної держави-члена та допомагають їм 11 Генеральних адвокатів. Обов'язком Генеральних адвокатів $€$ надання обгрунтованих висновків по справах, в яких вони беруть участь. Сам по собі інститут Генеральних адвокатів був взятий за аналогією з посадою французьких урядових комісарів, які працюють у фрранцузькому Conseil d'Etat. Вже стало практикою призначати чотирьох Генеральних адвокатів, що є громадянами найбільших держав - членів СС, тобто Німеччини, Франції, Іспанії, Італії. Інші п'ять Генеральних адвокати призначаються державами-членами у порядку ротації за алфравітом. У Договорі про фрункціонування ЄC передбачена можливість збільшити кількість Генеральних адвокатів за постановою Ради на вимогу Суду СС [5].

До вступу в силу поправок Лісабонського договору судді Суду ЄC, Генеральні адвокати обиралися за спільною згодою урядів на строк 6 років 3 осіб, чия незалежність не викликала сумніву та які мають кваліфікацію, необхідну для призначення на найвищі судові посади в їх 
державі. Після поправок 2009 р. був змінений порядок призначення суддів цих ланок та Генеральних адвокатів на посаду. Для цього передбачено створення колегії для надання висновків по кандидатурах на посаду суддів та Генеральних адвокатів, яка буде складатися з сімох осіб, що є колишніми суддями Суду ЄС, Загального суду, членів нащіональних вищих судів та визнаних правників, один 3 яких запропонований Свропейським Парламентом (ст. 255 Договору о фрункціонуванні ЄС). Тільки після консультаціі з цією групою держави-члени можуть призначити за спільною згодою на посаду суддю або Генерального адвоката [6].

3 огляду на збільшення судових процесів та надмірну тривалість судових розглядів у справах, Трибунал перейменували в Загальний суд, що утворився у складі 54 суддів (2 судді від кожної країни $(С)$ : це є наслідком судової редpopми 2016 р., згідно з якою кількість суддів була збільшена до двох від кожної держави-члена до 2019 р., та виходу Великобританії з СС наприкінщі січня 2020 р. Судді призначаються за спільною згодою урядів держав-членів після консультацій з колегією, відповідальною за надання висновку щодо придатності потенщійних кандидатів для виконання відповідних обов'язків. Термін їх повноважень також становить шість років і може бути поновлений. Судді Суду аналогічно Суду СС, обирають з-поміж себе Голову, а також призначають секретаря строком на шість років. Судді виконують свої обов'язки абсолютно неупереджено та незалежним чином. На відміну від Суду ЄC, Загальний суд не має постійних генеральних адвокатів. Однак це завдання може, за виняткових обставин, виконувати один із суддів.

Отже, до складу судової системи ЄС входить Європейський Суд (справедливості) та Загальний суд.

Стосовно повноважень то Суд СС приймає рішення щодо справ, які є у його провадженні. Найпоширеніші типи справ стосуються таких аспектів:

- тлумачення джерел (попередні рішення) - національні суди держав-членів повинні забезпечити правильне застосування права СC, але суди різних країн можуть тлумачити його по-різному. Якщо національний суддя сумнівається у тлумаченні чи обгрунтованості законодавства СС, він може звернутися до Суду за роз'ясненнями. Той самий механізм може бути використаний для визначення відповідності національного законодавству СС;
- забезпечення дотримання законодавства (процедури порушення) - такий тип дій вживається проти уряду держави-члена СС, який не поважає законодавство ЄС. Позов може ініціювати Європейська комісія або дудь-яка державачлен СС. У випадку, якщо країна не виконуе вимоги, їі потрібно негайно виправити, інакше це ризикує повторною процедурою, яка може призвести до штрафру;

- скасування юридичних актів СС (дії про скасування) - якщо держава-член СС вважає, що акт СС порушує договори або основні права СС, уряд держави-члена, може подати позов через Суд ЄС до: Ради ЄС, Свропейської Комісію або навіть Європейського Парламенту. Уряд держави-члена може просити Суд скасувати такий акт. Громадяни також можуть попросити Суд скасувати акт СС, який безпосередньо стосуеться їх особисто;

- забезпечення дії СС (апелящії щодо бездіяльності) - за певних обставин Парламент, Рада та Комісія повинні приймати певні рішення. В іншому випадку уряди держав-членів СС, установи $Є C$ та за певних умов, навіть громадяни ЄС або підприємства можуть звертатися до Суду;

- санкціонування відшкодування шкоди завданої установами СС (відшкодування збитків) - будь-який громадянин або підприемство, інтереси якого були порушені внаслідок дії чи бездіяльності інституцій СС або його персоналу, може подати позов на них до Суду [7].

Висновки. Отже, судова система Європейського Союзу включає дві ланки: Суд ЄС та Загальний Суд. До повноважень Суду ЄС входить правове регулювання: тлумачення джерел, забезпечення дотримання законодавства, скасування юридичних актів ЄС, забезпечення дії ЄС, санкціонування відшкодування шкоди установами СС.

Розвиток судової системи СС відображує вагомий внесок у розбудові інституційної системи органів СС та у створенні правового підгрунтя для захисту прав та свобод людини і громадянина в ЄС.

Лісабонська угода внесла значну кількість змін у фрункціонування Суду $\mathrm{CC}$, проте не дала відповіді на всі існуючі питання і лише спровокувала внесення додаткових змін у структуру і повноваження суду ЄС, що є підставою для проведення нових грунтовних наукових досліджень у сорері впливу Суду СС на судову систему держав-членів СС і подальшу рефрорму структури та розширення повноважень Суду ЄС.

\section{Список літератури:}

1. Голуб К.Ю. Решение суда европейских сообществ как источник права ЕС : дис. ... канд. юрид. наук : 12.00 .10$. Саратов, 2009. С. 3-4.

2. Яковюк І.В. Правові основи інтеграції до ЄС: загальнотеоретичний аналіз : монографія. Харків, 2013.760 с.

3. Протокол (№ 3) про Статут Суду Свропейського Союзу (Протокол про Статут Суду Європейського економічного співтовариства). ЄEC, Європейський Союз; Протокол, Статут, Міжнародний документ від 17.04.1957 (Ред. від 13.12.2007). URL: https://zakon.rada.gov.ua/laws/show/994_618\#Text (дата звернення: 24.04.2021).

4. Аналіз статусу Генеральних адвокатів у судовій системі ЄC, зв'язку їх статусу з розвитком прецедентного права Суду ЄC див.: Burrows N., Greaves R. The Advocate General and EC Law. Oxford : Oxford University Press, 2007. 317 c.

5. Комарова Т.В. Юрисдикція Суду Свропейського Союзу : монографія. Харків, 2010. 360 с.

6. Камінська I.B. Судова система СС: Гносеологічні засади функціонування та розвитку. Часопис Київського університету права. Київ, 2020. № 1.47 с.

7. Офіційний сайт Суду Свропейського Союзу (СC). URL: https://europa.eu/european-union/about-eu/institutionsbodies/court-justice_en (дата звернення: 24.04.2021). 


\section{References:}

1. Golub K.Yu. (2009) The decision of the court of European communities as a source of EU law: dis. ... cand. jurid. science: 12.00 .10 . Saratov, pp. 3-4.

2. Yakovyuk I.V. (2013) Legal basis of integration into the EU: general theoretical analysis: monograph. Kharkiv, 760 p.

3. Protocol (№ 3) on the Statute of the Court of Justice of the European Union (Protocol on the Statute of the Court of Justice of the European Economic Community). EEC, European Union; Protocol, Statute, International Document dated April 17, 1957 (Ed. Dated December 13, 2007). URL: https://zakon.rada.gov.ua/laws/show/994_618\#Text (accessed 24 April 2021).

4. For an analysis of the status of Advocates General in the EU judiciary, the relationship between their status and the development of case law of the Court of Justice, see: Burrows N., Greaves R. The Advocate General and EC Law. Oxford: Oxford University Press, 2007. 317 p.

5. Komarova T.V. (2010) Jurisdiction of the Court of Justice of the European Union: monograph. Kharkiv, 360 p.

6. Kaminskaya I.V. (2020) Judicial system of the EU: Epistemological principles of functioning and development. Journal of Kyiv University of Law. Kyiv, no. 1, 47 p.

7. Official site of the Court of Justice of the European Union (EU). URL: https://europa.eu/european-union/about-eu/ institutions-bodies/court-justice_en (accessed 24 April 2021). 